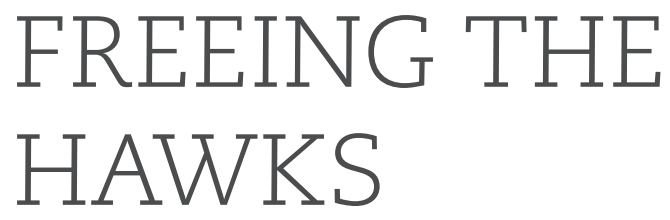

\title{
Why an anti-corruption agency should not be in the SAPS
}

\author{
IRVIN KINNES* AND GARETH NEWHAM** \\ Irvin.Kinnes@uct.ac.za \\ gnewham@issafrica.org
}

The Directorate for Priority Crime Investigation (DPCI), commonly known as the 'Hawks', is currently at a crossroads. The Constitutional Court judgment in Glenister vs the President of South Africa and Others has called into question the Directorate's continued existence in its current form. One of the most important questions raised by the Constitutional Court judgment is whether the DPCI can be sufficiently independent while located within the SAPS. This article presents arguments in support of the view that separating the unit from the SAPS is essential to build public confidence in the unit and to meet the requirements of the judgment.

International experience suggests that combating organised crime and corruption can only be successful if there is a strong political commitment on the part of governments to tackle these challenges. ${ }^{1}$ Unsurprisingly, countries that experience a high level of corruption by politicians and high-ranking civil servants are unlikely to formulate a suitable institutional response to corruption. It follows that those who abuse state resources will not be dealt with effectively.

In the case of Glenister vs. the President of the Republic of South Africa and Others (hereafter referred to as 'the Glenister case'), the South African Constitutional Court noted that:

Corruption has become a scourge in our country and it poses a real danger to our developing democracy. It undermines the ability of the government to meet its commitment to fight poverty and to deliver on other social and economic rights guaranteed in our Bill of Rights.

* Irvin Kinnes is a PhD student at the Centre of Criminology at the University of Cape Town.

** Gareth Newham is head of the Crime and Justice Programme at the Institute for Security Studies.
Organised crime and drug syndicates also pose a real threat to our democracy. ${ }^{2}$

This, then, is the situation, despite the South African government undertaking to tackle organised crime and corruption through the ratification of a range of $\mathrm{UN}$ instruments aimed at committing member states to doing so. ${ }^{3}$ Included in these international agreements is the requirement for states to establish an independent body to fight organised crime and corruption. ${ }^{4}$

The Directorate for Priority Crimes Investigation (DPCI), commonly known as the 'Hawks', was established in South Africa in 2009 to fight 'priority crimes', including organised crime and corruption. The unit took over from its predecessor, the Directorate of Special Operations (DSO), commonly known as the 'Scorpions'. The Scorpions were disbanded following a decision by the ruling African National Congress (ANC) during its 2007 National Conference at which Jacob Zuma was elected president of the party.

As a consequence of the Constitutional Court judgment the DPCI is now at a crossroads. 
Important decisions need to be made by the legislature with respect to the mandate, location and structure of the unit. Key to these decisions is whether the Directorate can be adequately independent, as required by the Constitution and international law, while remaining a unit of the SAPS. This article argues that in order for the DPCI to be effective as an organised agency fighting crime and corruption, it has to exist separately from the SAPS.

\section{CONTEXT}

In a report to the Portfolio Committee for Justice and Constitutional Development in October 2011, the head of the Special Investigating Unit (SIU), Willie Hofmeyr, stated that corruption involving government procurement was costing South Africa as much as R30 billion each year. ${ }^{5} \mathrm{He}$ noted that his unit was investigating 588 procurement contracts to the value of R9.1 billion and 360 conflict of interest matters to the value of R3.4 billion. ${ }^{6}$ These were matters related to public sector corruption only, and did not include corruption in the private sector where no public money was involved (for instance, through collusion to reduce competition). In addition, the 2010/11 SAPS Annual Report recorded that the police were investigating 179 organised crime groups, up from 145 groups two years previously. In a Justice Crime Prevention and Security Cluster (JCPS) briefing on 18 February 2012, the Minister of Justice and Constitutional

Development, Jeff Radebe, reported that the total value of assets frozen, involving 157 suspects under investigation for priority crimes, was R579 million. ${ }^{8}$

Corruption appears to have permeated the executive itself. Two Cabinet members were fired towards the end of 2011 for their roles in scandals in which it was alleged that they had abused their powers to irregularly benefit themselves or those connected to them. Minister for Public Works, Gwen Mahlangu-Nkabinde, was removed for her role in the awarding of two tenders worth $\mathrm{R} 1,116$ billion and R604 million respectively to a politically well-connected businessman, Roux Shabangu, for the lease of new premises for the
SAPS at well above market-related prices. ${ }^{9}$ In addition, Minister for Cooperative Governance and Traditional Affairs, Sicelo Shiceka, was fired, amongst other things for misusing hundreds of thousands of rands in state resources to visit a girlfriend in a Swiss prison. ${ }^{10}$

Between 2007 and 2011 South Africa fell ten points (from a rating of 5.1 to 4.1 ) on the Transparency International Corruption Index. ${ }^{11}$ This resulted in the country's lowest score since the establishment of the index. Thus the Constitutional Court judgment on the DPCI comes at a time when there are indications that levels of organised crime and corruption are worsening. Consequently, pressures on the executive to deal with corruption have increased, with citizens starting to take the initiative to hold government to account. For example, the Constitutional Court judgment on the legislation establishing the Hawks was the result of a case brought by a private citizen, Hugh Glenister. Early in 2012, the trade union federation COSATU, in partnership with other organisations, formed Corruption Watch, a new non-governmental organisation to expose corruption and hold government to account for acts of corruption by civil servants and politicians. (See the interview with David Lewis, Director of Corruption Watch, in this edition of SACQ.)

At the end of 2012 the African National Congress will hold its elective congress in Mangaung. ${ }^{12}$ The last conference, held in 2007, saw President Thabo Mbeki ousted from his position as president of the ruling party, and replaced by Jacob Zuma. The conference this year is likely to be as highly contested and fraught, as factions within the ruling party and its alliance partners (the South African Communist Party and COSATU) fight each other for position.

Any structure that investigates corruption and organised crime, as the DPCI is mandated to do, is sure to find itself having to investigate politicians, high-level civil servants and politically connected business people. When it does so, it will come under intense political pressure as powerful individuals seek to protect themselves or 
their associates. This will place tremendous pressure on the DPCI, as any investigation it may conduct into allegations of corruption by ANC members who hold political office may be interpreted as being politically motivated. ${ }^{13}$

\section{POLITICAL INTERFERENCE IN THE SAPS}

The possibility of political interference in the SAPS was identified in the Glenister Judgment as compromising the independence of the DPCI. In this section of the article we present recent examples of apparent political interference in the SAPS.

Firstly, there is no requirement that the National Commissioner has to be a police officer, or a person who has the skills, experience or personal integrity necessary to effectively manage a large police organisation. The independence of the SAPS is consequently undermined by the fact that the appointment might be based on political position or status. The two most recent SAPS National Commissioners were appointed primarily because of their long-standing membership and political seniority in the ANC, and had no policing experience. Candidates for the post of National Commissioner are also not subject to a transparent screening process to determine whether they are suitable for the position.

At the time of writing the National Commissioner of Police, Bheki Cele, had been suspended and was facing a judicial inquiry to determine whether he was fit for office. His suspension resulted from his authorisation of the deal to lease premises from Shabangu (referred to above in relation to the Minister of Public Works). Although an investigation by the Public Protector into the lease deal found that Cele had acted irregularly and illegally, ${ }^{14}$ the matter was not referred for criminal investigation (as had been the case when allegations of corruption arose against the former National Commissioner, Jackie Selebi). Rather, the matter was referred to a board of inquiry, which did not have powers of investigation or subpoena, and was thus less likely to find evidence relating to corruption, than if the board had such powers.
One of the clearest signs of direct political interference in the SAPS involves the appointment of the Head of Crime Intelligence, LieutenantGeneral Richard Mdluli. Two months after Jacob Zuma was sworn in as president, Mdluli was irregularly appointed to this position. While the SAPS Act requires that the National Commissioner appoint the deputy national and divisional commissioners, ${ }^{15}$ acting National Commissioner at the time, General Tim Williams, revealed that he was excluded from the process of interviewing and appointing Mdluli. Instead the interview was conducted by a panel consisting of only four cabinet members and no police officials. ${ }^{16}$ It was reported in the media that Mdluli was appointed to this position because President Jacob Zuma believed he owed Mdluli a favour for having assisted him to escape various criminal charges. ${ }^{17}$

A short while later, Mdluli was investigated by the Hawks and charged with murder and corruption. ${ }^{18}$ During his bail hearing Mdluli argued that the charges had no substance but were motivated by a political conspiracy against him. To support this claim, he handed as evidence to the court a 'ground intelligence report', providing details about various senior ANC politicians and claiming that they had met to discuss unseating Zuma as president at the upcoming 2012 ANC National Conference. ${ }^{19}$ Mdluli's statement that he had presented Zuma with this report could easily be read as evidence of the abuse of state resources, and his official police position, because it showed that he had used police intelligence resources to spy on senior ANC politicians.

However, after representations made by his lawyers behind closed doors, the National Prosecuting Authority (NPA) controversially withdrew the criminal charges against Mdluli. ${ }^{20}$ What made this particularly controversial is that prior to dropping the charges the NPA had commissioned an independent legal opinion, which found that there was sufficient evidence to prosecute him.

More recently it was reported that the head of the Hawks, Lieutenant-General Anwar Dramat, had 
shelved criminal investigations into Mdluli and other members of the SAPS Crime Intelligence Division, involving widespread misuse of police resources, allegedly on instruction from the current Acting National Commissioner, General Nhlanhla Mkhwanazi. ${ }^{22}$

In another example of possible political interference in the SAPS, the media reported at the end of March that members of the VIP unit protecting Zuma had been irregularly promoted, some jumping as many as six ranks and tripling their salaries in a single promotion, in contravention of current guidelines. ${ }^{23}$

Whether or not political interference will ultimately be found to have taken place, the very public nature of the various allegations and the refusal of the SAPS to comment on what it has termed an internal matter, has created the perception that the SAPS is subject to political interference.

\section{POLICE CORRUPTION AND PUBLIC PERCEPTIONS}

It is important for a unit tasked with investigating corruption and organised crime to have credibility amongst citizens, and to enjoy public confidence. ${ }^{24}$ Pierre de Vos has argued that the Constitutional Court judgment in the Glenister case held that 'the state could not create a body that it claimed was independent but that did not appear independent to the reasonable member of the public': ${ }^{25}$

[P]ublic confidence in mechanisms that are designed to secure independence is indispensable. Whether a reasonably informed and reasonable member of the public will have confidence in an entity's autonomy-protecting features is important to determining whether it has the requisite degree of independence.

Hence, if Parliament fails to create an institution that appears from the reasonable standpoint of the public to be independent, it has failed to meet one of the objective benchmarks for independence. This is because public confidence that an institution is independent is a component of, or is constitutive of, its independence. ${ }^{26}$

Since its establishment in 1995 the SAPS has struggled to contain corruption amongst its own members, not least at the highest level of the organisation. David Bruce has argued that '[n]ot only has the SAPS actively undermined its corruption control mechanisms but it has done so whilst management systems, which constitute the basic mechanism of control, have been undermined. ${ }^{27}$ This seems to be supported borne out by evidence of a high level of reported police corruption. The Minister of Police, Nathi Mthethwa, reported that in the 2010 and 2011 financial years there were 1061 investigations into corruption committed by members of the SAPS. ${ }^{28}$ In Gauteng alone, 469 police officers were arrested and charged for corruption between September 2010 and October 2011. ${ }^{29}$

This has had an effect on public perceptions of the police. Studies have shown that for many years, a significant proportion of the public have viewed the SAPS as untrustworthy and corrupt. ${ }^{30}$ The 2011 Victims of Crime Survey conducted by Statistics South Africa noted that of those who admitted paying a bribe to a public official over the previous 12 months, $21,4 \%$ involved the police, representing an increase from the $18.6 \%$ who admitted doing so in $2007 .{ }^{31}$ Of those who stated that they were dissatisfied with the police, $46,6 \%$ blamed corruption as the cause of their unhappiness.

This would suggest that for the DPCI (or another anti-corruption agency) to enjoy public confidence it would need to be independent of the police. If the DPCI were to remain a unit of the SAPS, the head of the DPCI would remain subordinate to the National Commissioner, and the National Commissioner would remain responsible for determining the budget of the unit. ${ }^{32}$ Moreover, DPCI members would wear the same uniforms, drive the same vehicles and be held accountable by the same policies and procedures as the rest of the SAPS. Thus, from the point of view of a member of the public, there would be no reason to view the DPCI differently to any other unit of the SAPS. 


\section{THE SAPS AMENDMENT BILL}

It took a great deal of time and effort, and a case that went all the way to the Constitutional Court, but in March 2011 businessman Hugh Glenister successfully challenged the legislation that replaced the Scorpions with the Hawks. ${ }^{33}$ The Court found that that the DPCI was not adequately protected from political interference or influence, for the following reasons:

- The DPCI reported to the National Commissioner, who was a political appointee

- There was inadequate job security and secured remuneration for the head of the DPCI and its members, as the National Commissioner could redeploy them at any time for any reason

- The head of the DPCI was subordinate to a Ministerial Committee and National Commissioner who could determine which cases it investigated

- The SAPS National Commissioner determined whether prosecutors could assist the DPCI with its investigations

- Parliament's powers of oversight were insufficient to prevent political interference from the executive

- The complaints mechanism of the DPCI was inadequate to prevent interference, as the National Director of Public Prosecutions could refuse requests from the complaints judge to provide information ${ }^{34}$

- The members of the DPCI were not required to take an oath committing to impartiality. ${ }^{35}$

The Court ruled that structural and operational independence of the unit was vital to exclude undue political interference in the DPCI. However, the Court stopped short of indicating where a unit responsible for investigating corruption should be located. In a clear reference to its placement and operational and institutional independence, the judgment noted that it was:

[p]ermissible to locate anti-corruption agencies within existing structures such as the NPA and the SAPS. However, the independence of the law enforcement bodies that are institutionally placed within existing structures in the form of specialised departments or units requires special attention. The centralised and the hierarchical nature of their structures and the fact that they report at the final level to a Cabinet minister, as in the case of the police and the NPA, present a risk of interference. The risk of undue interference is even higher when members of the unit lack autonomous decision-making powers and where their superiors have discretion to interfere in a particular case. What is required are legal mechanisms that will limit the possibility of abuse of the chain of command and hierarchical structure or interference in the operational decisions involving commencement, continuation and termination of criminal investigations and prosecutions. ${ }^{36}$

The UN Convention against Corruption determines that the state should facilitate the necessary independence of such structures. Article 6(2) of the Convention states:

Each State Party shall grant the body or bodies referred to in paragraph 1 of this article the necessary independence, in accordance with the fundamental principles of its legal system, to enable the body or bodies to carry out its or their functions effectively and free from any undue influence. The necessary material resources and specialised staff, as well as the training that such staff may require to carry out their functions, should be provided.

The SAPS Amendment Bill (Bill 7 of 20120) that was tabled in Parliament in March 2012 retains the DPCI as a directorate of the SAPS, but seeks to address the Constitutional Court's concerns by making a few structural changes to the DPCI. These are:

- The head of the DPCI will be appointed by the Minister of Police, with the approval of Cabinet (Section 17 C). This means that the National Commissioner cannot appoint or remove the head of the DPCI.

- The head of the DPCI will have the authority to arrange for the secondment of staff from other departments (Section 17F). 
- The DPCI head, rather than the National Commissioner, will have the authority to accept cases referred by provincial commissioners or the National Commissioner for investigation (Section 17D).

- The DPCI head will have the authority to overrule a decision by the National Commissioner should a dispute arise about which cases fall within the remit of the DPCI.

- Security vetting of DPCI members may be undertaken by an intelligence structure other than SAPS Crime Intelligence (Section 9A).

While the above clauses may appear to address the issue of the DPCI's independence, these measures are undermined by the fact that the Bill provides for the budget of the Directorate to be determined by the National Commissioner of Police.

Moreover, in terms of the requirements of the Public Finance Administration Act 1999 (Act 29 of 1999), the Commissioner will remain the accounting officer for the SAPS, including the DPCI.

It seems clear that the DPCI cannot be 'adequately' independent if its head does not have control over the Directorate's operational and administrative budget. Moreover, as the accounting officer for the DPCI, the National Commissioner would have reason to assess the performance and functioning of the Directorate in great detail. This may result in a form of indirect interference, which could fall foul of the requirements of the Constitutional Court judgment for independence.

\section{CONCLUSION}

Any agency that investigates corruption by politicians, high-ranking civil servants and powerful businessmen will come under tremendous political pressure and interference. It is thus important for such a unit to be insulated, at least as far as possible, from this pressure. This is best achieved if the independence of the agency and its staff is promoted and protected in law. As long as the unit is located within the SAPS it cannot be adequately protected from political influence, and there are many ways in which its work can be interfered with.
It is also necessary for an agency that is tasked with countering corruption to enjoy public confidence. Over the past sixteen years the SAPS has failed to address corruption within its ranks. In addition, two successive National Commissioners of Police have been implicated in unlawful activities (with the former head, Jackie Selebi having been convicted for corruption). It is thus unlikely that the unit will be able to engender public confidence while it is part of the SAPS. This strongly suggests that there is a need to separate the DPCI from the SAPS if it is to be effective. The process of realigning the DPCI with the Constitutional Court provisions should be seen as an opportunity to establish the best possible anti-corruption agency as an investment in the future of South Africa. The SAPS

Amendment Bill does not achieve this. It is therefore up to the Portfolio Committee on Police to subject this draft legislation to rigorous scrutiny and strengthen it substantially to avoid the courts having to step in yet again.

To comment on this article visit

http://www.issafrica.org/sacq.php

\section{NOTES}

1. A Hübschle, Organised Crime in Southern Africa, First Annual Review 85, Pretoria: ISS, 2010.

2. Constitutional Court of SA, Case CCT 48/10 [2011] ZACC 6, Glenister $v$ State President of the Republic of South Africa, [57] 28.

3. UN Convention Against Transnational and Organised Crime as adopted on 15 November 2000 and UN Convention Against Corruption, as adopted on 31 October 2003.

4. Article 6 (2), UN Convention Against Corruption, 2003.

5. See http://www.corruptionwatch.org.za/content/ economic-implications (no author, accessed $29 \mathrm{March}$ 2012).

6. Parliamentary Monitoring Group, Minutes of the Justice and Constitutional Committee meeting held 11 October 2011, available at: http://www.pmg.org.za/ report/20111012-special-investigating-unit-its-annualreport-201011 (Accessed 9 January 2012).

7. SAPS Annual Report 2008/2009, 111.

8. Minister Jeff Radebe: Justice, Crime Prevention and Security (JCPS) cluster media briefing, 19 Feb 2012, available at: http://www.info.gov.za/speech/Dynamic Action? pageid $=461 \& \operatorname{sid}=25162 \&$ tid $=56876$ (Accessed 4 March 2012).

9. N Bauer, Protector rips into Mahlangu-Nkabinde over leasing scandal, Mail \& Guardian, 14 July 2011, available at: http://mg.co.za/article/2011-07-14- 
protector-rips-into-mahlangunkabinde-over-leasingscandal (Accessed 13 March 2012).

10. Public Protector of the Republic of South Africa, In the extreme: Report No.11 of 2011/12 of the Public Protector on an investigation into allegations of a Breach of the Executive Ethics Code by the Minister of Cooperative Governance and Traditional Affairs, $\mathrm{Mr}$ Sicelo Shiceka, MP available at: http://www.pprotect. org/library/investigation_report/Shiceka\%20Report\%20Final\%20version\%207-signed.pdf.

11. Transparency International, Corruption Perception Index, available at http://www.transparency.org/ policy_research/surveys_indices/cpi (Accessed 26 March 2012).

12. The Policy Conferences prepare for the National Conference which is held every five years and adopts new policies for the organisation. The National Conference elects new leaders to the National Executive Committee.

13. M Mkhabela, It's a Witch Hunt - Yengeni, City Press, 1 October 2001, available at http://www.armsdealvpo.co.za/articles00/witch_hunt.html.

14. Public Protector, Against the Rules Too, Report of the Public Protector in terms of Section 182(1) of the Constitution of the Republic of South Africa, 1996 and Section 8(1) of the Public Protector Act, 1994 on an investigation into complaints and allegations of maladministration, improper and unlawful conduct by the Department of Public Works and the South African Police Service (SAPS) relating to the leasing of SAPS accommodation in Durban, 2011, available at http://www.publicprotector.org/library/investigation_r eport/investigation_report.asp, (accessed 29 March 2012).

15. SAPS Act 1995 (Act 68 of 1995), Chapter 4, Section 6(2).

16. P Harper, The key players in the dirty police file saga, City Press, 18 March 2012, 5.

17. S Sole and S Evans, President Zuma's phalanx of praetorian guards, Mail \& Guardian, 23 March 2012, available at http://mg.co.za/article/2012-03-23-zumaspraetorian-guards (Accessed 26 March 2012).

18. SAPA, Mdluli faces fraud, corruption charges, Mail \& Guardian, 22 September 2011, available at http://www.news24.com/SouthAfrica/News/Mdlulifaces-fraud-corruption-charges-20110922 (Accessed 18 March 2012).

19. M Rossouw, Mdluli fires the gun on 2012 race, Mail \& Guardian, 15 April 2011, available at http://mg.co.za/ article/2011-04-15-mdluli-fires-the-gun-on-2012-race (Accessed 18 March 2012).

20. SAPA, Charges to be dropped, no trial for Mdluli, news 24.com, available at http://www.news24.com/ SouthAfrica/News/Charges-to-be-dropped-no-trialfor-Mdluli-20120202 (Accessed 18 March 2012).

21. A Basson, NPA 'abandoned' legal opinion, City Press, 18 March 2012, 4.

22. P Harper and A Basson, Zuma's spy's dirty files, City Press, 18 March 2012, 1.

23. C du Plessis, Top jobs for Zuma's cops, City Press, 25 March 2012, available at: http://www.citypress.co.za/ Politics/News/Top-jobs-for-Zumas-cops-20120324 (Accessed 29 March 2012).
24. P de Vos, The South African Police Service Amendment Bill 2012: An opinion on compliance with the Constitutional Court judgment Glenister $v$ President of the Republic of South Africa \& others, Legal opinion for the ISS, 19 March 2012, 6.

25. P de Vos, Glenister: A monumental judgment in defense of the poor, constitutionallyspeaking.co.za available at http://constitutionallyspeaking.co.za/ glenister-a-monumental-judgment-in-defence-of-thepoor/ (Accessed 18 March 2012).

26. P de Vos, The South African Police Service Amendment Bill 2012: An opinion on compliance with the Constitutional Court judgment Glenister v President of the Republic of South Africa \& others, Legal opinion for the ISS, 19 March 2012, 6.

27. D Bruce, Benign Neglect: The Politics and Practice of Controlling Police Corruption in South Africa, paper presented at the Annual Bank Conference on Development Economics, CSVR, 2008, 9.

28. See http://www.info.gov.za/speech/DynamicAction? pageid $=461 \& \operatorname{sid}=19444 \&$ tid $=35935($ Accessed 5 March 2012).

29. SAPS, Gauteng clamps down on corrupt cops, 3 November 2011, available at: http://www.news24.com/ SouthAfrica/News/Gauteng-clamps-down-on-corruptcops-20111103 (Accessed 1 April 2012).

30. G Newham and A Faull, Protector or Predator, Tackling Police Corruption in South Africa, ISS Monograph 182, Pretoria: ISS, 2011, 13, available at http://www.iss.org. za/pgcontent.php?UID=31046 (Accessed 14 January 2012).

31. Victims of Crime Survey, Statistics South Africa, 2011, 4.

32. SAPS Amendment Bill 2012, s17H.

33. Victory a sting in the tail, Mail \& Guardian, editorial, 18 March 2012, available at http://mg.co.za/article/ 2011-03-18-victory-a-sting-in-the-tail (Accessed 29 March 2012).

34. S17L(1)(a) of the SAPS Amendment Act 57 of 2008 makes provision for a complaints procedure against the DPCI to be handled by a retired judge.

35. Constitutional Court of SA, Case CCT 48/10 [2011] ZACC 6 , Glenister $v$ State President of the Republic of South Africa, para218, 113.

36. Ibid, 64 .

37. At the time of writing, section $17 \mathrm{H}$ of the SAPS Amendment Bill 2012 gave the National Commissioner of Police the authority to determine the budget of the Directorate, after consultation with the head of the DPCI.

38. Newham and Faull, Protector or Predator?, 2011, available at http://www.iss.org.za/pgcontent.php?UID= 31046 (Accessed 14 January 2012). 